\title{
Corporate governance and firm performance: Evidence from Vietnamese listed companies
}

\author{
Pham Thi Ngoc Bich ${ }^{1}$, Nguyen Dinh Hoang Uyen ${ }^{1 *}$ \\ ${ }^{1}$ University of Economics Ho Chi Minh City, Vietnam \\ *Corresponding author: hoanguyen@ueh.edu.vn
}

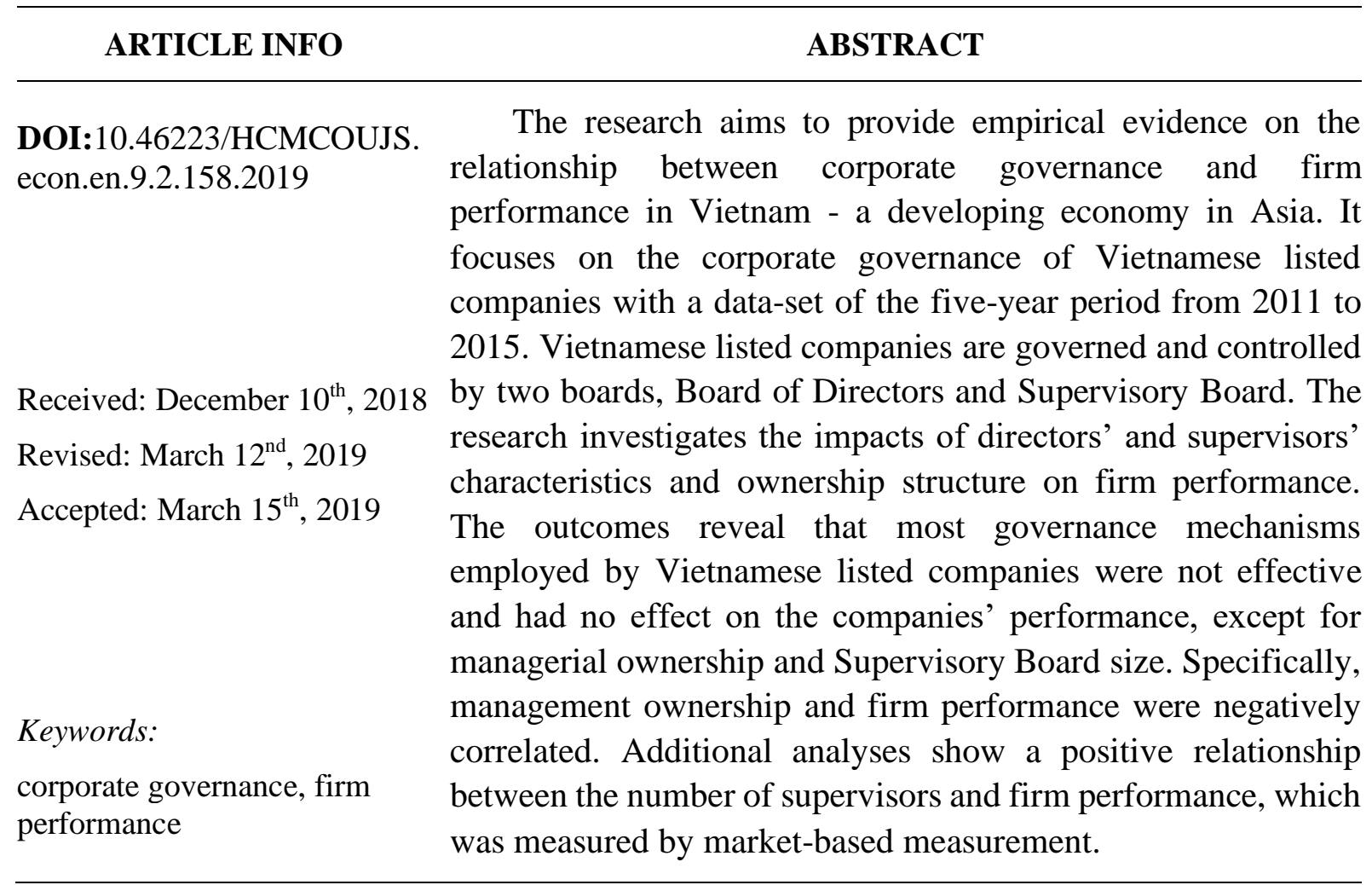

\section{Introduction}

Recently, corporate governance has acquired great attention from academics, policymakers and practitioners. Companies that are perceived to have better corporate governance receive more trust from investors and usually enjoy a lower cost of capital and higher market valuation than others (Bai, Liu, Lu, Song, \& Zhang, 2004). From a macroeconomic perspective, the Organization for Economic Co-operation and Development (2004) stated that corporate governance is critically important to a country's economic growth and stability because it provides the credibility and confidence, which are fundamental to the efficiency and efficacy of capital markets. As a result, the research in the field of corporate governance has been increasing. In the same time, legal frameworks as well as good practices of corporate governance have been enhanced in many countries.

Literature has been marked by many studies on the relationship between corporate governance and firm performance in both developed countries and developing nations. Nevertheless, there is little attention to the relationship between corporate governance and firm 
performance in Vietnam. Our research would provide a more comprehensive and reliable picture of the relationship between corporate governance and firm performance in Vietnamese listed companies. In addition, our research findings could provide more initiatives to listed companies in pursuing their objective regarding good corporate governance.

The study uses a data set of 146 listed companies in Ho Chi Minh Stock Exchange (HOSE) over a period from 2011 to 2015. Financial information and non-financial information pertaining to the characteristics of the board of directors, supervisory board, ownership structure and audit firm are obtained from annual reports which were hand collected from hsx.vn (HOSE's website), cafef.vn and cophieu68.vn. Firm performance is captured using the return on total assets (ROA), return on total equity (ROE) and Tobin Q. Corporate governance is measured by the size of the board of directors, CEO duality, director's independence, managerial ownership, state ownership, supervisory board's size and independence and audit quality. Firm size and financial leverage are two control variables.

The study employs regression analysis to examine the relationship between corporate governance and firm performance in Vietnam. Because the data set used is panel data, so we run 3 models Pooled OLS, FEM, and REM, after that, we use F test and Hausman test to choose the model which is the most explaining the relationship.

The report consists of five sections. In Section 2, Literature Review, we review the theoretical background as well as empirical literature on the relationship between corporate governance and firm performance. The particular characteristics of Vietnamese corporate governance structure and the research's hypothesis development are also explained in this section. Section 3 discusses the research design and methodology that explains how to collect and analyze the data to achieve the research's objectives. The research's findings are presented in the fourth section. In this part, a discussion of the research's results is also included. The final section summarizes the research's objectives, its results and contributions as well as its limitations and future research direction.

\section{Literature review}

\subsection{Foundational theories and key governance models in the world}

Although the literature covers a wide variety of theories underpinning the concept of corporate governance, two mainly accepted theoretical foundations are agency theory and stakeholder theory. At the same time, there are two main models of corporate governance, namely the one-tier and two-tier board models.

Agency theory and one-tier board model

The focus of agency theory is to deal with the conflicts in the relationship of shareholders and managers, which result from the separation of ownership from control in modern corporations (Fama, 1980; Fama \& Jensen, 1983; Jensen \& Meckling, 1976). In this theory, shareholders are referred to as 'the principal', and managers are assumed to be 'the agent'. From these studies, it can be understood that agency problems are likely costly and could harm a company's performance.

The one-tier board model was built upon the agency theory. The key feature of the one- 
tier model is the role of Board of Directors in controlling the managers' discretion (Bohinc, 2011; Nikolic \& Erk, 2011). The board represents the shareholders in order to solve these agency conflicts which can arise between the shareholders and the managers.

\section{Stakeholder theory and two-tier board model}

Stakeholder theory extends the boundary of accountability in agency theory. While agency theory highlights that the firm is accountable to its shareholders only (Jensen \& Meckling, 1976), stakeholder theory emphasizes that the firm has to discharge its accountability to all stakeholders rather than only shareholders (Freeman, 1984). Stakeholders represent any group or individual who can affect or is affected by the achievement of the firm's objectives. In other words, they have a stake in the firm along with shareholders, managers, employees, suppliers, customers, financiers, government and community.

The two-tier board model is based on stakeholder theory. The system relies on Supervisory Board, which usually consists of shareholder representatives, employee representatives and creditor representatives. There are two boards in the corporate governance structure, namely the supervisory board and the management board; they are totally separate and independent (Douma, 1997; Millet-Reyes \& Zhao, 2010). The supervisory board plays the role of governance. The management board performs management duties and is supervised by Supervisory Board. According to Law on Enterprises (National Assembly of Vietnam, 2014), Vietnamese listed companies have two boards in their governance structure including the supervisory board and the board of directors. However, Vietnam did not adopt purely the twotier board model; the governance system of Vietnamese listed companies employs the characteristics of both the one-tier and two-tier models. Vietnamese companies are actually monitored by both supervisory board and non-executive/outside directors. Owing to particular Vietnamese governance structure, this research will examine the impact of the characteristics of the supervisory board on firm performance in addition to the conventional governance mechanisms which also includes characteristics of the board of directors, ownership structure, and audit quality.

\subsection{Empirical literature and hypothesis development}

The relationship between corporate governance and firm performance has been widely investigated in developed countries (Bauwhede, 2009; Sueyoshi, Goto, \& Omi, 2010; Ward, Brown, \& Rodriguez, 2009). In developing nations, researchers have gradually paid more attention to this topic, particularly in China (Shan \& McIver, 2011). However, there is little research on the relationship between corporate governance and firm performance in Vietnam. Vo and Phan (2013) examined and confirmed the association between board characteristics and firm performance in Vietnamese listed companies. In addition, Vo and Nguyen (2014) investigated the relationship of board characteristics, CEO's and Board's ownership and firm performance in Vietnam.

One key problem of the two studies is that they'd assumed Vietnamese governance structure was the one-tier board model. As a result, the research investigated only the impact of Board of Directors on firm performance and forgot the role of Supervisory Board. As mentioned above, Vietnamese listed companies are monitored by both Supervisory Board and independent 
directors. Furthermore, although Vo and Nguyen (2014) took into account the impact of ownership structure on firm performance, they focused only on the managerial ownership. However, most Vietnamese listed companies were State-owned enterprises; the influence of the State on corporate governance is likely significant. Consequently, it is necessary to examine the impact of supervisory board member characteristics as well as State ownership on firm performance. It provides initiatives to conduct this research.

The research extends the understanding of corporate governance in Vietnam by investigating the impact of both the characteristic of Board of directors and Supervisory board on firm performance. Moreover, the relationship of ownership structure including managerial as well as State's shareholdings is investigated in the research. Furthermore, the research also examines one key governance mechanism that has not been investigated yet, it is audit quality. In brief, the research would provide a more comprehensive and reliable picture of the relationship between corporate governance and firm performance in Vietnamese listed companies.

Together with the development of the stock market in Vietnam, there are increasingly active and knowledgeable investors. Vietnamese listed companies have thus paid more attention to improving their corporate governance. Our research findings could provide more initiatives to listed companies in pursuing their objective regarding good corporate governance.

\section{Board of Directors' characteristics and firm performance}

\section{Board size}

Some researchers argued that larger board size implied the board possessed greater collective information as well as provided alot of experienced and technical-skilled members who could support and improve monitoring ability (Mohapatra, 2017). However, Nguyen, Rahman, Tong, and Zhao, (2016) and Palaniappan (2017) suggested that larger boards might be less effective than small boards in monitoring management due to coordination problems and director free-riding. Vietnam likely meets the same problems of coordination and freeriding, so the hypothesis is constructed as below:

Hypothesis 1 (H1): There is a negative association between board size and firm performance

\section{CEO duality}

CEO duality refers to the situation in which a CEO is also the company's chairman. Beasley (1996) pointed out that the appointment of the CEO to the Chairman could lead to the concentration of power and possible conflicts of interest. The concentration of power in the hand of a CEO through duality may lead to opportunistic and inefficient behavior that reduces shareholder wealth (Jensen \& Meckling, 1976). Therefore, advocates of agency theory argue for independence in a company's leadership structure where there is a separation between the CEO and the chairman, which could ensure that the CEO runs the company in the shareholders' interests. In other words, CEO duality could lead to lower firm performance. In addition, Vo and Nguyen (2014) confirmed the negative association of CEO duality and firm performance in Vietnamese listed companies, thus the following hypothesis is made: 
Hypothesis 2 (H2): There is a negative relationship between CEO duality and firm performance

\section{Board's Independence}

Agency theorists support that non-executive directors or outside directors contribute to monitor opportunistic behavior of executive directors (Jensen \& Meckling, 1976). Additionally, according to Chancharat, Krishnamurti, and Tian (2012), Fields and Keys (2003), Nugroho and Eko (2011), Zahra and Pearce (1989) the presence of non-executive directors in the board may improve the quality and deliberation of board decision-making process, ensuring that management is acting in the best interests of shareholders. Therefore, they believed that the independence of board enhances firm performance. The hypothesis was constructed as below:

Hypothesis 3 (H3): There is a positive relationship between the number of nonexecutive directors and firm performance

\section{Ownership structure and firm performance}

\section{Managerial ownership}

Jensen and Meckling (1976) predicted that low levels of insider ownership imply poor alignment of interest between management and shareholders. Therefore, ownership of a firm's shares by the management team is seen as a method to constrain some opportunistic behaviors of managers which may be harmful to the interests of shareholders. However, some research conducted in developing countries showed a negative correlation between managerial ownership and firm performance due to principle - principle problems between more powerful shareholders and less powerful shareholders (Shan, 2013; Yang, Lin, \& Yen, 2012). As Vietnam is also a developing country, the same relationship is expected.

Hypothesis 4 (H4): There is a negative relationship between the proportion of shares held by the management team and firm performance

\section{State's ownership}

The State plays an important role in the Vietnamese economy. Thanks to the privatization process, State-owned enterprises have significantly been reduced. However, the State still holds a certain percentage of Vietnamese listed companies' shares. More importantly, the State has a power to intervene to the company's operation that the other shareholders have not. Some research proved that State ownership could result in poor performance (Banca \& Trento, 1997; Shen \& Lin, 2009).

Hypothesis 5 (H5): There is a negative relationship between the proportion of shares held by the State and firm performance

\section{Supervisory Board's characteristics and firm performance}

In practice, the majority listed companies in Vietnam are governed by two boards, namely Board of Directors (board) and Supervisory Board. Basically, Supervisory Board has the responsibility to monitor the board's activities (Bezemer, Peij, de Kruijs, \& Maassen, 2014; Nietsch, 2005). The research will focus on the relationship between the characteristics of Supervisory Board, including such as the size and the independence of Supervisory Board, and 
firm performance.

\section{Supervisory Board's size}

The size of supervisory board is gauged through the number of members. Although the literature provides an extensive discussion of the audit committee supervisory board's size- firm performance relationship, the reported results are still inconclusive. However, some recent studies conducted in developing countries such as Ghabayen (2012), Mohd (2011), Nuryanah and Islam (2011) and Wei (2007) reported a positive relationship between the size of Supervisory Board and firm performance. On the basis of these findings, the researcher formulates the following hypothesis:

Hypothesis 6 (H6): There is a positive relationship between supervisory board size and firm performance

\section{Independence of Supervisory Board}

In practice, many members of the Supervisory Board of Vietnamese listed companies are their full-time employees. As a result, outside members may improve the independence of Supervisory Board, which in turn might result in a company's high performance $(\mathrm{Hu}, \mathrm{Tam}, \&$ Tan, 2010). Therefore, the research proposes the following hypothesis:

Hypothesis 7 (H7): The proportion of outside supervisors on the supervisory board is positively related to firm performance

\section{Audit quality and firm performance}

In the literature of corporate governance, external audit is considered as a watchdog of a company's shareholders. Thanks to its expertise and independence, the external audit may well perform its role in controlling a company's managers. Dobre and Brad (2015) pointed out that audit quality has a statistically positive effect on firm performance. Francis and Yu (2009) have found that larger offices of Big 4 auditors have higher quality audits for SEC registrants due to greater in-house experience in administering such audits. The final hypothesis is thus constructed as follows:

Hypothesis 8 (H8): Audit quality (Big4 or non-Big4) is positively related to firm performance

\section{Data and methodology}

\subsection{Data - sample collection}

This study used a data set of 146 listed companies in Ho Chi Minh Stock Exchange (HOSE) in the period 2011-2015. The initial sample was 304 firms listed as the industrycategorized-list in the HOSE's website, however, banks, insurance companies and other financial institutions were excluded as the preparation of their financial statements is different. Plus, those firms which missing financial or governance information were also excluded (we collected all data by hand via some websites such as cafef.com or cophieu68.com and companies' website, some companies have not published their reports in these websites or in their reports some non- financial information was lost, therefore the size of sample was reduced). After these exclusions were made, the sample of the study was limited to 146 firms 
with a total of 730 firm-year observations.

\subsection{Measurement of variables}

\subsubsection{Firm performance - Dependent variable}

Firm performance is captured using return on total assets (ROA), return on total equity (ROE) and Tobin Q. In this work, the ROA and ROE, the accounting-based measures, are used because they relate directly to management's ability to efficiently utilize corporate assets and equity indicates what management has accomplished with the given resources. Additionally, accounting estimation is directly concerned with profitability and a firm's survival. In this study, ROA and ROE are calculated by the ratio between net income and total assets (ROA) and total stockholder's equity (ROE). The total asset and total stockholder's equity are estimated by the average of beginning and ending figures in a financial year. These ratios are used to measure firm performance in studies by (Bhagat \& Bolton, 2008; Klapper \& Love, 2002). The use of both accounting and market measures of firm performance will enforce the result of the study.

\subsubsection{Corporate governance variables - Independent variables}

This research will extend the understanding of corporate governance in Vietnam by investigating the impact of both Board of Directors, Supervisory Board and Audit quality on firm performance, therefore, in the main regression model, there are eight variables pertaining to corporate governance characteristics including Board size (BSZ), CEO duality (DUAL), Board independence (BNED), ownership structure (SD and SS), Supervisory Board size (SSZ), Independence of Supervisory Board (SNED) and Audit quality (AUD).

Board size (BSZ) is considered as an important role on firm performance (Bhagat \& Bolton, 2008). In emerging countries, according to Malaysian Code of Corporate Governance 2000, the optimal size of Board of Directors should be determined by the whole board to ensure that there are enough members to discharge responsibilities and perform various functions (Rahman \& Ali, 2006). While, in corporate governance regulation in Vietnam, the Ministry of Finance regulates Circular 121/2012/TT-BTC mentioned specifically that the number of Board should be at least three and maximum is eleven members. In this study, the size of the Directors board, which mentioned in hypothesis $\mathrm{H} 1$ is measured by the total number of members on the board. According to H1, it is believed that large board size will constrain firm performance, thus predicted sign is negative.

CEO duality (DUAL) presented when the CEO is also the Chairman. This is the most common dependent variable used in many studies which research in this field such as Baliga, Moyer, and Rao (1996), Boyd (1995), Rechner and Dalton (1991), In this work, CEO duality is a dummy variable which first taking the value of 1 if the CEO served as the chairman of the board and 0 otherwise. Following hypothesis H2, the predicted sign is negative.

Board's independence (BNED) is considered as one of factors affecting the efficiency and effectiveness of board.

Based on the rule of Vietnam Ministry of Finance in Circular 121/2012/TT-BTC, the structure of Board of Directors should be maintained the balance between executive directors 
and non-executive directors, particularly, at least 1/3 of total members on the board are nonexecutive directors. ${ }^{1}$

In our study, the independent level of the board is measured by the number of nonexecutive directors divided by the total number of board members. As mentioned in hypothesis $\mathrm{H} 3$, it is believed that the large proportion of non-executive directors may improve the quality and deliberation of the board decision-making process, therefore, lead to higher firm performance. The authors predicted that this relation might be a positive correlation.

Ownership structure is also considered as the critical factor having a significant influence on firm performance. According to the circular 52/2012/TT-BTC of Ministry of Finance of Vietnam which providing guidelines for financial disclosure in the stock market, a shareholder with 5\% voting right in a public company is considered as a significant shareholder. In this study, ownership structure includes managerial ownership (SD), which is measured as the percentage of shares held by Management Team and related parties, 2 and State ownership (SS), which is measured by the proportion of shares held by State.

According to $\mathrm{H} 4$, it is believed that there is a positive relationship between the proportion of shares held by the management team and firm performance while there is a negative relationship between the proportion of shares held by the State and firm performance (H5).

Supervisory board's size (SSZ) is measured by the total number of members in the Supervisory Board. Based on the results of recent studies, it is believed that there is no relationship between supervisory board size and firm performance.

Independence of Supervisory Board (SNED) is also considered as the characteristics of corporate governance which have affected on firm performance. A supervisory board that is comprised of more number of non-executive directors is deemed more independent than one that has more executive directors (Rahmat, Iskandar, \& Saleh, 2009). The independent level is measured by the proportion of outside supervisors on the supervisory board. Following hypothesis $\mathrm{H} 7$, the predicted sign of this variable is positive.

The last variable is audit quality (AUD). In theory, external audit is considered as a

\footnotetext{
${ }^{1}$ Circular 121/2012/TT-BTC also stipulates that independent members must meet all the requirements as follows:

i. They are non-executive members. The non-executive member is not director, vice-director, chief accountant or others who hold managerial positions, which are appointed by board of directors.

ii. They are not members of the board, director, vice director of subsidies, cooperative companies, which are controlled by the listed company.

iii. They are not large shareholders or representatives and relatives of large shareholders.

iv. They do not work for law consultancy or auditing firms of the listed company in the most recent two years.

v. They are not the suppliers or customers, which account for $30 \%$ of transaction values in the most recent two years.

${ }^{2}$ Related parties of Management Team are people who have a close relationship with the members in Management Team. For example: Wife, Son, Daughter, Sister, and Brother.
} 
watchdog of a company's shareholders; therefore, it is believed that the quality of external audit affect on firm performance. In this study, this variable is a dummy variable that taking the value of 0 if the company's audit firm is Big4 firms (including KPMG, PwC, EY, and Deloitte) and 1 otherwise. It is believed that audit quality will increase firm performance.

\subsubsection{Control variables}

Firm size (FSIZE) and financial leverage (LEV) effect are considered as the factors determined by the relationship between corporate governance and firm performance (Zahra \& Pearce, 1989; Vo \& Nguyen, 2014); therefore, we used them as control variables.

The log of total assets is also included in order to control the size of the firm (FSIZE) as some prior research studies found that there is an effect on firm performance. Besides that, Joh (2003) believed that Financial Leverage (LEV) which is calculated by long-term debt divides total equity impact on firm performance.

Table 1 summarizes all variables measurement used in the study.

\section{Table 1}

A summary of variables used

\begin{tabular}{|c|c|c|c|}
\hline Variables & Definition & Measurement & Predicted sign \\
\hline \multicolumn{4}{|l|}{$\begin{array}{l}\text { Dependent } \\
\text { variables }\end{array}$} \\
\hline \multirow[t]{2}{*}{ ROA } & \multirow[t]{2}{*}{ Return on asset } & \multicolumn{2}{|l|}{ Earnings after tax } \\
\hline & & Total asset & \\
\hline \multirow[t]{2}{*}{ ROE } & \multirow[t]{2}{*}{ Return on equity } & Earnings after tax & \\
\hline & & Total equity & \\
\hline \multirow[t]{2}{*}{ Q } & \multirow[t]{2}{*}{ Tobin's Q } & $\begin{array}{l}\text { Total asset }+ \text { market value of equity - } \\
\text { book value of equity - deferred taxes }\end{array}$ & \\
\hline & & Total assets & \\
\hline \multicolumn{4}{|c|}{$\begin{array}{l}\text { Independent } \\
\text { variables }\end{array}$} \\
\hline BSZ & Board size & The total number of board members & - \\
\hline DUAL & CEO Duality & $\begin{array}{l}\text { Coded } 1 \text { if CEO is also the } \\
\text { chairman of the board of directors; } \\
\text { otherwise, the value is } 0 \text {. }\end{array}$ & - \\
\hline BNED & $\begin{array}{l}\text { Board's } \\
\text { Independence }\end{array}$ & $\begin{array}{l}\text { The number of non-executive } \\
\text { directors divided by the total } \\
\text { number of board members }\end{array}$ & + \\
\hline SD & $\begin{array}{l}\text { Managerial } \\
\text { ownership }\end{array}$ & $\begin{array}{l}\text { The proportion of shares held by } \\
\text { Management Team and related } \\
\text { parties }\end{array}$ & - \\
\hline SS & State ownership & $\begin{array}{l}\text { The proportion of shares held by the } \\
\text { State }\end{array}$ & - \\
\hline SSZ & Supervisory & $\begin{array}{l}\text { The total number of members in } \\
\text { the Supervisory board }\end{array}$ & + \\
\hline
\end{tabular}




\begin{tabular}{|c|c|c|c|}
\hline Variables & Definition & Measurement & Predicted sign \\
\hline \multirow[b]{2}{*}{ SNED } & board's size & & \\
\hline & $\begin{array}{l}\text { Independence of } \\
\text { Supervisory } \\
\text { Board }\end{array}$ & $\begin{array}{l}\text { The proportion of outside } \\
\text { supervisors on the supervisory } \\
\text { board }\end{array}$ & + \\
\hline AUD & Audit quality & $\begin{array}{l}\text { Coded } 0 \text { if the company' audit } \\
\text { firm is Big4 firms (including } \\
\text { KPMG, PwC, EY and Deloitte) } \\
\text { and } 1 \text { otherwise. }\end{array}$ & - \\
\hline \multicolumn{4}{|l|}{$\begin{array}{l}\text { Control } \\
\text { variable }\end{array}$} \\
\hline FSIZE & Firm size & Log (Total asset) & \\
\hline LEV & $\begin{array}{l}\text { Financial } \\
\text { Leverage }\end{array}$ & Long term debt/ Total assets & \\
\hline
\end{tabular}

Source: The researcher's data analysis

\subsection{Regression equations}

The study firstly ran FEM and REM models and after that used the Hausman test to choose the right model to regress the relationship between corporate governance and firm performance. Besides, we used robust test to detect heteroskedasticity and auto-correlation.

Firstly, we ran 3 models below to test the relationship between corporate governance and firm performance measured by accounting-based and market-based proxies.

There are three equations as below:

Equation 1 (E1)

$$
\mathrm{ROA}_{\mathrm{i}, \mathrm{t}}=\begin{array}{lllllll}
\alpha 0+\alpha 1 & \mathrm{BSZ}_{\mathrm{i}, t}+\alpha 2 & \mathrm{DUAL}_{\mathrm{i}, \mathrm{t}}+\alpha 3 & \mathrm{BNED}_{\mathrm{i}, \mathrm{t}}+\alpha 4 & \mathrm{SD}_{\mathrm{i}, \mathrm{t}}+\alpha 5 & \mathrm{SS}_{\mathrm{i}, \mathrm{t}}+\alpha 6 & \mathrm{SSZ}_{\mathrm{i}, \mathrm{t}}+\alpha 7 \\
\mathrm{SNED}_{\mathrm{i}, \mathrm{t}}+\alpha 8 \mathrm{AUD}_{\mathrm{i}, \mathrm{t}}+\alpha 9 \mathrm{FSIZE}_{\mathrm{i}, \mathrm{t}}+\alpha 10 \mathrm{LEV}_{\mathrm{i}, \mathrm{t}}+\varepsilon_{\mathrm{i}, \mathrm{t}} & & & &
\end{array}
$$

Equation 2 (E2)

$$
\mathrm{ROE}_{\mathrm{i}, \mathrm{t}}=\begin{array}{llllllll}
\alpha 0+\alpha 1 & \mathrm{BSZ}_{\mathrm{i}, t}+\alpha 2 & \mathrm{DUAL}_{\mathrm{i}, \mathrm{t}}+\alpha 3 & \mathrm{BNED}_{\mathrm{i}, \mathrm{t}}+\alpha 4 & \mathrm{SD}_{\mathrm{i}, \mathrm{t}}+\alpha 5 & \mathrm{SS}_{\mathrm{i}, t}+\alpha 6 & \mathrm{SSZ}_{\mathrm{i}, t}+\alpha 7 \\
& \mathrm{SNED}_{\mathrm{i}, \mathrm{t}}+\alpha 8 \mathrm{AUD}_{\mathrm{i}, \mathrm{t}}+\alpha 9 \mathrm{FSIZE}_{\mathrm{i}, \mathrm{t}}+\alpha 10 \mathrm{LEV}_{\mathrm{i}, \mathrm{t}}+\varepsilon_{\mathrm{i}, \mathrm{t}} & & & & &
\end{array}
$$

Equation 3 (E3)

Tobin $\mathrm{Q}_{\mathrm{i}, t}=\alpha 0+\alpha 1 \quad \mathrm{BSZ}_{\mathrm{i}, t}+\alpha 2 \quad \mathrm{DUAL}_{\mathrm{i}, \mathrm{t}}+\alpha 3 \mathrm{BNED}_{\mathrm{i}, \mathrm{t}+\alpha 4} \mathrm{SD}_{\mathrm{i}, t}+\alpha 5 \mathrm{SS}_{\mathrm{i}, t}+\alpha 6 \mathrm{SSZ}_{\mathrm{i}, t}+\alpha 7$ $\mathrm{SNED}_{\mathrm{i}, t}+\alpha 8 \mathrm{AUD}_{\mathrm{i}, t}+\alpha 9$ FSIZE $_{\mathrm{i}, \mathrm{t}}+\alpha 10 \mathrm{LEV}_{\mathrm{i}, \mathrm{t}}+\varepsilon_{\mathrm{i}, \mathrm{t}}$

where $\mathrm{ROA}_{\mathrm{i}, \mathrm{t}}, \mathrm{ROE}_{\mathrm{i}, \mathrm{t}}, \mathrm{Q}_{\mathrm{i}, \mathrm{t}}$ indicate firm performance indicators (FP), BSZ $\mathrm{i}_{\mathrm{i}, \mathrm{t}}, \mathrm{DUAL}_{\mathrm{i}, \mathrm{t}}$, $\mathrm{BNED}_{\mathrm{i}, \mathrm{t}}, \mathrm{SD}_{\mathrm{i}, \mathrm{t}}, \mathrm{SS}_{\mathrm{i}, \mathrm{t}}, \mathrm{SSZ}_{\mathrm{i}, \mathrm{t}}, \mathrm{SNED}_{\mathrm{i}, \mathrm{t}}, \mathrm{AUD}_{\mathrm{i}, \mathrm{t}}$ are a vector of corporate governance variables and FSIZE $_{i, t}, L_{E V} V_{i, t}$ are a vector of control variables for firm $i$ at time t. $\alpha 0$ and $\alpha 1$ to $\alpha 10$ are intercept and parameters to be estimated, respectively. $\varepsilon_{\mathrm{i}, \mathrm{t}}$ is the error term.

\section{Data analysis and discussion}

\subsection{Descriptive statistics}


Table 2 provides descriptive statistics for variables in three models. Panel A reports about the financial variables used in the calculation of firm performance, while panel B shows the descriptive statistics including mean, standard deviation, minimum, median and maximum for each continuous variable in the main regression models. In addition, Panel $\mathrm{C}$ displays the summary of dummy regression variables.

\section{Table 2}

Descriptive statistics

Panel A: Financial variables

\begin{tabular}{lccccc}
\hline & N & Mean & Std. Deviation & Minimum & Maximum \\
\hline ROA \% & 730 & 5.71 & 6.8 & -15.9 & 39.27 \\
ROE \% & 730 & 10.27 & 11.78 & -60.45 & 55.24 \\
Tobin's Q & 730 & 0.99 & 0.43 & 0.35 & 5.84 \\
\hline
\end{tabular}

Panel B: Continuous regression variable

\begin{tabular}{lccccc}
\hline & N & Mean & Std. Deviation & Minimum & Maximum \\
\hline BSZ & 730 & 5.71 & 1.21 & 3 & 11 \\
BNED\% & 730 & 0.60 & 0.19 & 11.11 & 100 \\
SD \% & 730 & 9.75 & 15.13 & 0 & 77.6 \\
SS\% & 730 & 21.08 & 24.55 & 0 & 79.69 \\
SSZ & 730 & 3.05 & 0.35 & 2 & 5 \\
SNED \% & 730 & 83.59 & 30.78 & 0 & 100 \\
FSIZE & 730 & 12.08 & 0.52 & 11.11 & 14.16 \\
LEV & 730 & 0.11 & 0.14 & 0 & 0.67 \\
\hline
\end{tabular}

Panel C: Dummy regression variable

\begin{tabular}{lcc}
\hline & Obs & Percentage \\
\hline DUAL & 730 & $27.53 \%$ \\
AUD & 730 & $29.45 \%$ \\
\hline
\end{tabular}

Source: The researcher's data analysis

In panel $\mathrm{A}$, ROA has a mean value of $5.71 \%$ with a standard deviation of $6.8 \%$, while these figures of ROE are $10.27 \%$ and $11.78 \%$ for mean and standard deviation respectively. Tobin's Q ratio presents an average of nearly 1 with a standard deviation of 0.43 .

In terms of the continuous variables in the regression model related to corporate governance characteristics, panel B reports detail six variables including the number of members in the board, the proportion of non-executive directors in the board of directors, the proportion of shares held by the Management Team and related parties, the percentage of shares held by the State, the number of Supervisory Board's members, the proportion of outside 
members in Supervisory board and two control variables. Regarding board size, the number of total members in listed companies in Vietnam ranges from three to eleven, it aligns in the regulation mentioned in the Circular 121/2012/TT-BTC of Ministry of Finance which rules that the number of board's members should be at least three and the maximum is eleven members. While the number of supervisors ranges from 2 to 5 with an average of 3.04. In addition, panel $\mathrm{B}$ indicates that the mean of the percentage of outside members in Supervisory board is $83.59 \%$ with a standard deviation of $30.78 \%$.

Panel C presents that $27.53 \%$ of firms in which CEO is also the chairman of board. This proportion is quite low in comparison with $66.9 \%$ of the sample of Malaysian and Singapore of Bradbury, Mak, and Tan (2006). Besides, it is reported that only $29.45 \%$ of research firms were audited by the Big Four firms.

\subsection{Regressions results and discussion}

Table 3 below shows the test results for the two most moderate problems in OLS regression models: heteroskedasticity and serial correlation. Panel A indicates that all models contain heteroskedasticity because of the Prob. Chi-Square is 0.000 .

\section{Table 3}

Test of heteroskedasticity and autocorrelation

Panel A: Breusch- Pagan/Cook- Weisberg test for heteroskedasticity

\section{$\begin{array}{lll}\text { Equation } 1 & \text { Equation 2 } & \text { Equation } 3\end{array}$}

\begin{tabular}{llll}
\hline Chi-square & 604.23 & 306.42 & 586.92 \\
Prob> Chi-square & 0.0000 & 0.0000 & 0.0000
\end{tabular}

Source: The researcher's data analysis

Panel B provides the information about correlations between dependent and independent variables in the main regression model. The highest correlation of the independent variable is -0.467 via the relationship between Audit quality and Firm size. Therefore, it means that there is not the existence of multicollinearity in this model.

Panel B: Pearson correlation matrix of variables in three regression models

\begin{tabular}{|c|c|c|c|c|c|c|c|c|c|c|c|c|c|}
\hline & 1 & 2 & 3 & 4 & 5 & 6 & 7 & 8 & 9 & 10 & 11 & 12 & 13 \\
\hline (1) ROA & 1 & & & & & & & & & & & & \\
\hline (2) ROE & - & 1 & & & & & & & & & & & \\
\hline (3)Q & - & - & 1 & & & & & & & & & & \\
\hline (4)BSZ & .003 & .050 & .091 & 1 & & & & & & & & & \\
\hline (5)DUAL & -.042 & -.054 & -.014 & -.078 & 1 & & & & & & & & \\
\hline (6)BNED & .029 & .002 & .041 & .043 & -.308 & 1 & & & & & & & \\
\hline (7) $\mathrm{SD}$ & -.176 & -.158 & -.063 & .027 & .343 & -.145 & 1 & & & & & & \\
\hline (8) $\mathrm{SS}$ & .037 & .055 & .033 & -.130 & -.220 & -.096 & -.307 & 1 & & & & & \\
\hline
\end{tabular}




\begin{tabular}{|c|c|c|c|c|c|c|c|c|c|c|c|c|c|}
\hline & 1 & 2 & 3 & 4 & 5 & 6 & 7 & 8 & 9 & 10 & 11 & 12 & 13 \\
\hline (9)SSZ & .059 & .108 & .234 & .387 & -.078 & .074 & -.004 & .069 & 1 & & & & \\
\hline (10)SNED & -.099 & -.133 & -.021 & .032 & -.023 & .109 & -.058 & -.068 & .010 & 1 & & & \\
\hline (11) AUD & -.019 & -.010 & -.173 & -.140 & .142 & -.100 & .047 & -.034 & -.191 & -.080 & 1 & & \\
\hline (12)FSIZE & -.121 & -.021 & .232 & .315 & -.058 & -.046 & .119 & .056 & .325 & .071 & .467 & 1 & \\
\hline (13) LEV & -.264 & -.187 & -.023 & .213 & -.064 & -.105 & .063 & .121 & .121 & -.015 & -.096 & .432 & 1 \\
\hline
\end{tabular}

Source: Extracted from Stata v12

The results in regression model indicate that the linear equation E1, E2, and E3 is relevant and proper for studying the relationship between corporate governance (particularly board of directors, supervisory board characteristics and audit quality) and firm performance (which is measured by ROA, ROE and Tobin's Q) as Sig. Value $=.000$. We ran 3 models Pooled OLS, FEM REM, after that we used F-test and Hausman test to choose the most appropriate model. The results show that REM seems to be more appropriate for E1 and E2 and FEM for E3.

\section{Table 4}

F test and Hausman test result

Panel A: F Test

Prob $>\mathrm{F}$

\section{Equation $1 \quad$ Equation 2}

0.0002

Denied Ho

Choose FEM

Equation 1

7.15

0.7112

Accepted Ho

Choose REM

0.0047

Denied Ho

Choose FEM

Equation 2

12.09

0.2793

Accepted Ho

Choose REM
Equation 3

0.0000

Denied Ho

Choose FEM

Chi-square

Prob> Chi-square

$\begin{array}{lll}\text { Accepted Ho } & \text { Accepted Ho } & \text { Denied Ho } \\ \text { Choose REM } & \text { Choose REM } & \text { Choose FEM }\end{array}$

Source: Data analysis result of the research

Table 5 shows the correlation among three models in which firm performance is measured by ROA, ROE and Tobin's Q.

Table 5

Result by using REM and FEM

\begin{tabular}{|l|c|c|c|c|c|c|}
\hline \multirow{2}{*}{ Model } & \multicolumn{2}{|l|}{ ROA (E1)- REM } & \multicolumn{2}{l|}{ ROE (E2)- REM } & \multicolumn{2}{c|}{ Tobin's Q (E3)- FEM } \\
\cline { 2 - 7 } & Coefficients & $\mathrm{p}>|\mathrm{z}|$ & Coefficients & $\mathrm{p}>|\mathrm{z}|$ & Coefficients & $\mathrm{p}>|\mathrm{t}|$ \\
\hline (Constant) & .029 & .078 & -.276 & .134 & -5.88 & .000 \\
\hline BSZ & .0001 & .953 & .0001 & .974 & -.010 & .531 \\
\hline DUAL & -.004 & .511 & -.007 & .530 & -.087 & .036 \\
\hline
\end{tabular}




\begin{tabular}{|l|c|c|c|c|c|c|}
\hline \multirow{2}{*}{ Model } & \multicolumn{2}{|l|}{ ROA (E1)- REM } & \multicolumn{2}{l|}{ ROE (E2)- REM } & \multicolumn{2}{l|}{ Tobin's Q (E3)- FEM } \\
\cline { 2 - 7 } & Coefficients & $\mathrm{p}>|\mathrm{z}|$ & Coefficients & $\mathrm{p}>|\mathrm{z}|$ & Coefficients & $\mathrm{p}>|\mathrm{t}|$ \\
\hline BNED & -.031 & .018 & -.038 & .149 & -.183 & .038 \\
\hline SD & -.065 & $\mathbf{. 0 0 4}$ & -.112 & $\mathbf{. 0 0 8}$ & -.328 & .066 \\
\hline SS & -.002 & .926 & -.003 & .932 & -.147 & .433 \\
\hline SSZ & .012 & .099 & .029 & .044 & .183 & $\mathbf{. 0 0 0}$ \\
\hline SNED & -.013 & .293 & -.046 & $\mathbf{. 0 3 0}$ & .239 & .055 \\
\hline AUD & -.001 & .876 & .005 & .710 & -.195 &. $\mathbf{0 0 0}$ \\
\hline FSIZE & .004 & .678 & .032 & .039 & .549 & .000 \\
\hline LEV & -.123 & .000 & -.190 & .000 & -.056 & .724 \\
\hline
\end{tabular}

Source: Summarized by the authors

\subsubsection{Impact of the characteristics of board of directors on firm performance}

In terms of the relationship between Board of Directors' characteristics and firm performance, this study fails to find the evidence to support the relationship between Board size and firm performance in all three measures of firm performance. This finding is consistent with the conclusion of Vo and Nguyen (2014) when they conducted the research with the data of listed Vietnamese companies from 2008 to 2012. Furthermore, we also fail to provide significant evidence to support the association between CEO duality, Board independence with the firm performance measured by accounting-based or market-based proxies.

Overall, the Board of Directors' attributes including Board size, Board duality, and Board independence do not likely affect firm performance. It is seemly contradictory to the socalled good practices of corporate governance around the world. However, it is well supported by empirical research, particularly for emerging economies in Asia (see Goh, Rasli, \& Khan, 2014; van Essen, van Oosterhout, \& Carney, 2012).

\subsubsection{Impact of ownership structure on firm performance}

Model 1 and 3 indicate that managerial ownership has a negative relationship with firm performance when the former is calculated by the proportion of shares held by Management Team and the latter are measured by ROA and Tobin's Q. Particularly, the negative coefficients are significant with p-value are .003 and $.008(<0.05)$. It means that when the percentage of shares owned by Management Team and by their related persons increases, the firm's performance likely decreases. The negative relationship between management ownership and firm performance found in the study is similar to the research on corporate governance in nonAnglo-American countries like Vietnam (Kumar \& Zattoni, 2015). It is explained by the principal-principal conflicts between dominant large shareholders-management and small shareholders-the other shareholders.

Meanwhile, the findings of the study fail to provide persuadable evidence of the relationship between State Ownership and Firm performance. It may be assumed that the State does not likely intervene in the operations of Vietnamese listed companies. In other words, the 
existence of the State does not likely affect firm performance.

\subsubsection{Impact of the characteristics of supervisory board on firm performance}

For Supervisory Board's size, there is a positive relationship between the number of supervisors and firm performance which is measured by Tobin's Q (with p-value $=0.000$ ). It indicates that when the number of Supervisory Board member increases, the market firm performance will grow. It might be the case that investors believe that the existence of more members in Supervisory Board will lead to an increase in their monitoring role, therefore, firm performance will be improved.

Turning to the effect of out-side Supervisors in the firm performance of the listed company, the study fails to find evidence to support the relationship between the percentage of outside members and firm performance for all three measurements. Actually, all Supervisory Board members are required to be outside according to the Enterprise Law 2014. Therefore, this finding could be understood in the case of Vietnam.

\subsubsection{Impact of audit quality on firm performance}

For audit quality perspective, there is a negative relationship between the quality of audit and firm performance which is measured by Tobin's Q (with p-value $=0.000$ ). The relationship between the audit firm and firm performance of the company shows that if the company is audited by Big4, the firm performance likely increases.

In summary, the outcomes reveal that most of governance mechanisms used by Vietnamese listed companies are not effective and do not affect the companies' performance, except for managerial ownership structure, Supervisory Board size and Audit Quality. Specifically, management ownership and firm performance are negatively correlated. Additional analyses present the positive relationship between the number of supervisors and firm performance, which is measured by market-based measurement.

\section{Conclusion}

\subsection{Conclusion and implications}

The paper investigates the relationship between corporate governance and firm performance in Vietnamese listed companies with a new data-set of the five-year period 20112015. We study both internal governance mechanisms including Board of Directors, Supervisory Board, ownership structure and external governance mechanism including audit quality. Firm performance is measured by both accounting-based and market-based.

The main findings of the study indicate that most of the governance mechanisms of Vietnamese listed companies are not effective and do not affect the companies' performance, except for managerial ownership structure, Supervisory Board size and Audit quality. Specifically, the proportion of shares held by Management Team and firm performance (which is measured by ROA and Tobin's Q) is negatively correlated. On the other hand, the empirical results of the study present the positive relationship between the number of supervisors and firm performance, which is measured by market-based measurement, Tobin's Q.

The research contributes to the governance research and practice in Vietnam as well as 
in other Asian emerging economies in several ways. First of all, the findings reveal that Vietnamese listed companies likely try to comply in appearance with the requirements on corporate governance regarding Board size, CEO duality, and Board independence. As a result, it does not lead to any impact on the performance of Vietnamese listed companies. In addition, due to weak investor protection by law, the expropriation of dominant shareholders, management, is serious, which results in a negative relationship between management ownership and firm performance. Furthermore, the stock market pays attention to the role of supervisory board, which is a special governance mechanism of Vietnamese listed companies. Unlike other countries where one-tier or two-tier board models are employed, Vietnamese listed companies have both a Board of Directors with non-executive members and a Supervisory Board which is independent from the Management. The outcomes of the research extend the existing literature on corporate governance by providing evidence on the role of Supervisory Board in improving the performance of Vietnamese listed companies. Therefore, it is suggested that the policy-maker need to enhance the role of supervisory board in corporate governance to improve the performance of Vietnamese listed companies.

\subsection{Limitations and future research direction}

There are some limitations in the study that provide initiatives for further research. We did not investigate the decision-making process, background and experience of both two boards including Board of Directors and Supervisory Board due to a lack of information available. When the study results reveal that there is no empirical evidence on the relationship of the characteristics of Board of Directors and firm performance, it is necessary to explore the reasons for such results by investigating deeply the Board's process and meetings. In addition, the board members' background and experience will contribute to explain their silence in the corporate governance's operation. Therefore, future research will carry out to fill in such gaps and uncover the reasons why there is no association between Board characteristics and firm performance in Vietnamese listed companies.

\section{References}

Bai, C.-E., Liu, Q., Lu, J., Song, F. M., \& Zhang, J. (2004). Corporate governance and market valuation in China. Journal of Comparative Economics, 32(4), 599-616. doi:10.1016/j.jce.2004.07.002

Baliga, B. R., Moyer, R. C., \& Rao, R. S. (1996). CEO duality and firm performance: What's the fuss?. Strategic Management Journal, 17(1), 41-53. doi:10.2307/2486936

Banca, F., \& Trento, S. (1997). State ownership and the evolution of Italian corporate governance. Industrial \& Corporate Change, 6(3), 533-559. doi:10.1093/icc/6.3.533

Bauwhede, H. (2009). On the relation between corporate governance compliance and operating performance. Accounting and Business Research, 39(5), 497-513. doi:10.1080/00014788.2009.9663380

Beasley, M. S. (1996). An empirical analysis of the relation between the board of director composition and financial statement fraud. The Accounting Review, 71(4), 443- 465. 
Bezemer, P.-J., Peij, S., de Kruijs, L., \& Maassen, G. (2014). How two-tier boards can be more effective. Corporate Governance: The International Journal of Business in Society, 14(1), 15-31. doi:10.1108/CG-02-2013-0018

Bhagat, S., \& Bolton, B. (2008). Corporate governance and firm performance. Journal of Corporate Finance, 14(3), 257-273. doi:10.1016/j.jcorpfin.2008.03.006

Bohinc, R. (2011). One or two-tier corporate governance systems in some EU and non EU countries. Megatrend Review, 8(1), 57-76.

Boyd, B. K. (1995). CEO duality and firm performance: A contingency model. Strategic Management Journal, 16(4), 301-312. doi:10.1002/smj.4250160404

Bradbury, M., Mak, Y. T., \& Tan, S. M. (2006). Board characteristics, audit committee characteristics and abnormal accruals. Pacific Accounting Review, 18(2), 4768. doi:10.1108/01140580610732813

Chancharat, N., Krishnamurti, C., \& Tian, G. G. (2012). Board structure and survival of new economy IPO firms. Corporate Governance an International Review, 20(2), 144-163. doi:10.1111/j.1467-8683.2011.00906.x

Dobre, F., \& Brad, L. (2015). A research regarding the influence of financial audit and of corporate governance on value relevance. Audit Financiar, 13(131), 116-126.

Douma, S. (1997). The two-tier system of corporate governance. Long Range Planning, 30(4), 612-614. doi:10.1016/S0024-6301(97)00047-2

Fama, E. F. (1980). Agency problems and the theory of the firm. Journal of Political Economy, 88(2), 288-307. doi:10.1086/260866

Fama, E. F., \& Jensen, M. C. (1983). Separation of ownership and control. Journal of Law and Economics, 26(2), 301-325. doi:10.1086/467037

Fields, M. A., \& Keys, P. Y. (2003). The emergence of corporate governance from Wall St. to Main St.: Outside directors, board diversity, earnings management, and managerial incentives to bear risk. The Financial Review, 38, 1-24. doi:10.1111/1540-6288.00032

Francis, J. R., \& Yu, M. D. (2009). Big 4 office size and audit quality. The Accounting Review, 84(5), 1521-1552. doi:10.2308/accr.2009.84.5.1521

Freeman, R. E. (1984). Strategic management: A stakeholder approach. Boston, MA: Pitman.

Ghabayen, M. (2012). Board characteristics and firm performance: Case of Saudi Arabia. International Journal of Accounting and Financial Reporting, 2(2), 168-200. doi:10.5296/ijafr.v2i2.2145

Goh, C. F., Rasli, A., \& Khan, S.-U.-R. (2014). CEO duality, board independence, corporate governance and firm performance in family firms: Evidence from the manufacturing industry in Malaysia. Asian Business \& Management, 13(4), 333-357. doi:10.1057/abm.2014.4

Hu, H. W., Tam, O. K., \& Tan, M. G.-S. (2010). Internal governance mechanisms and firm 
performance in China. Asia Pacific Journal of Management, 27(4), 727-749. doi:10.1007/s10490-009-9135-6

Jensen, M. C., \& Meckling, W. H. (1976). Theory of the firm: Managerial behavior, agency costs and ownership structure. Journal of Financial Economics, 3(4), 305-360. doi:10.1016/0304-405X(76)90026-X

Joh, S. W. (2003). Corporate governance and firm profitability: Evidence from Korea before the economic crisis. Journal of Financial Economics, 68(2), 287-322.

Kumar, P., \& Zattoni, A. (2015). Ownership structure, corporate governance and firm performance. Corporate Governance: An International Review, 23(6), 469-471. doi:10.1111/corg. 12146

Klapper, L. F., \& Love, I. (2002). Corporate governance, investor protection, and performance in emerging markets. Journal of Corporate Finance, 10(5), 703-728. doi:10.2139/ssrn.303979

Millet-Reyes, B., \& Zhao, R. (2010). A comparison between one-tier and two-tier board structures in France. Journal of International Financial Management \& Accounting, 21(3), 279-310. doi:10.1111/j.1467-646X.2010.01042.x

Ministry of Finance. (2012). Circular No. 121/2012/TT-BTC dated 26/07/2012 providing regulations on corporate governance applicable to public companies. Retrieved March 08, 2018, from http://www.ssc.gov.vn/ubck/faces/oracle/webcenter/portalapp/pages/en/legaldocume ntdetail.jspx?dDocName=APPSSCGOVVN162091217\&_afrLoop=5054380300970 00\&_afrWindowMode=0\&_afrWindowId=19252acv8e_1\#\%40\%3F_afrWindowId\% 3D19252acv8e_1\%26_afrLoop\%3D505438030097000\%26dDocName\%3DAPPSSC GOVVN162091217\%26_afrWindowMode\%3D0\%26_adf.ctrlstate\%3D19252acv8e_25

Mohapatra, P. (2017). Board size and firm performance in India. Vilakshan: The XIMB Journal of Management, 14(1), 19-30.

Mohd. T. (2011). The role of housing planning practices in contributing towards housing oversupply world academy of science. Engineering and Technology (WASET), 59, 767-775.

Nguyen, P., Rahman, N., Tong, A., \& Zhao, R. (2016). Board size and firm value: Evidence from Australia. Journal of Management \& Governance, 20(4), 851-873. doi:10.1007/s10997-015- 9324-2

Nietsch, M. (2005). Corporate governance and company law reform: A German perspective. Corporate Governance: An International Review, 13(3), 368-376. doi:10.1111/j.14678683.2005.00431.x

Nikolic, J., \& Erk, J. (2011). Boards of Directors models and role in corporate governance. Management (1820-0222), 16(60), 68-75. 
Nugroho, B. Y., \& Eko, U. (2011). Board characteristics and earning management. Journal of Administrative Science \& Organization, 18(1), 1-10.

Nuryanah, S., \& Islam, S. M. N. (2011). Corporate governance and performance: Evidence from an Emerging Market. Malaysian Accounting Review, 10(1), 17-42.

OECD. (2004). OECD principles of corporate governance. Retrieved March 10, 2018, from https://www.oecd.org/daf/ca/corporategovernanceprinciples/31557724.pdf

Palaniappan, G. (2017). Board characteristics relating to firm performance: A study on manufacturing firms in India. Journal of Commerce \& Accounting Research, 6(1), 2636.

Rahman, R. A., \& Ali, H. M. F. (2006). Board, audit committee, culture and earnings management: Malaysian evidence. Managerial Auditing Journal, 21(7), 783-804. doi:10.1108/02686900610680549

Rahmat, M. M., Iskandar, T. M., \& Saleh, N. M. (2009). Audit committee characteristics in financially distressed and non-distressed companies. Managerial Auditing Journal, 24(7), 624-638. doi:10.1108/02686900910975350

Rechner, P. L., \& Dalton, D. R. (1991). CEO duality and organizational performance: A longitudinal analysis. Strategic Management Journal, 12(2), 155-160.

Shan, Y. G. (2013). Can internal governance mechanisms prevent asset appropriation? Examination of type i tunneling in China. Corporate Governance: An International Review, 21(3), 225-241. doi:10.1111/corg.12022

Shan, Y. G., \& McIver, R. P. (2011). Corporate governance mechanisms and financial performance in China: Panel data evidence on listed non-financial companies. Asia Pacific Business Review, 17(3), 301-324. doi:10.1080/13602380903522325

Shen, W., \& Lin, C. (2009). Firm profitability, state ownership, and top management turnover at the listed firms in China: A behavioral perspective. Corporate Governance: An International Review, 17(4), 443-456. doi:10.1111/j.1467-8683.2009.00725.x

Sueyoshi, T., Goto, M., \& Omi, Y. (2010). Corporate governance and firm performance: Evidence from Japanese manufacturing industries after the lost decade. European Journal of Operational Research, 203(3), 724-736. doi:10.1016/j.ejor.2009.09.021

The National Assembly. (2014). Law on Enterprises. Retrieved February 15, 2018, from https://www.mzv.cz/public/6f/5/6b/1810642_1462220_Law_on_Enterprise_No_68_ 2014_English.pdf

van Essen, M., van Oosterhout, J. H., \& Carney, M. (2012). Corporate boards and the performance of Asian firms: A meta-analysis. Asia Pacific Journal of Management, 29(4), 873-905. doi:10.1007/s10490-011-9269-1

Vo, D. H., \& Nguyen, T. M. (2014). The impact of corporate governance on firm performance: Empirical study in Vietnam. International Journal of Economics and Finance, 6(6), 1-13. doi:10.5539/ijef.v6n6p1 
Vo, D. H., \& Phan, T. (2013). Corporate governance and firm performance: Empirical evidence from Vietnam. Journal of Financial Economics, 78, 210-226.

Ward, A. J., Brown, J. A., \& Rodriguez, D. (2009). Governance bundles, firm performance, and the substitutability and complementarity of governance mechanisms. Corporate Governance: An International Review, 17(5), 646-660. doi:10.1111/j.14678683.2009.00766.x

Wei, H. (2007). Financial integration and pricing of the world covariance risk: Large vs. small-cap stocks. Journal of International Money and Finance, 26(8), 1311-1337.

Yang, Y.-H., Lin, Y.-H., \& Yen, G.-F. (2012). A study on efficiency monitoring and interest assimilation in corporate governance: Listed companies in Taiwan. Emerging Markets Finance \& Trade, 48, 169-183. doi:10.2307/41739224

Zahra, S. A., \& Pearce, J. A. (1989). Boards of directors and corporate financial performance: A review and integrative model. Journal of Management 15(2), 291334. doi:10.1177/014920638901500208 